Widows' Words 



\title{
Widows' Words
}

\author{
WOMEN WRITE ON THE \\ EXPERIENCE OF GRIEF, \\ THE FIRST YEAR, \\ THE LONG HAUL, AND \\ EVERYTHING IN BETWEEN
}

8

Edited by Nan Bauer-Maglin 
Library of Congress Cataloging-in-Publication Data

Names: Maglin, Nan Bauer, editor.

Title: Widows' words : women write on the experience of grief, the first year, the long haul, and everything in between / edited by Nan Bauer-Maglin.

Description: New Brunswick, New Jersey : Rutgers University Press, [2019] | Includes bibliographical references.

Identifiers: LCCN 2018031137 | ISBN 9780813599533 (cloth: alk. paper)

Subjects: LCSH: Widows. | Widows in literature. | Grief. | Bereavement.

Classification: LCC HQ1058.W535 2019| DDC 306.88/3-dc23

LC record available at https://lccn.loc.gov/2018031137

A British Cataloging-in-Publication record for this book is available from the British Library.

"Eye Triptych" artwork on Parts II, III, and IV by Tara Sabharwal.

This collection copyright (๑) 2019 by Rutgers, The State University of New Jersey Individual chapters copyright (C) 2019 in the names of their authors All rights reserved

No part of this book may be reproduced or utilized in any form or by any means, electronic or mechanical, or by any information storage and retrieval system, without written permission from the publisher. Please contact Rutgers University Press, 106 Somerset Street, New Brunswick, NJ 08901. The only exception to this prohibition is "fair use" as defined by U.S. copyright law.

(9) The paper used in this publication meets the requirements of the American National Standard for Information Sciences-Permanence of Paper for Printed Library Materials, ANSI Z39.48-1992.

www.rutgersuniversitypress.org

Manufactured in the United States of America 
In memory of Jon-Christian Suggs 
